\title{
Isoflavones inhibit poly(l:C)-induced serum, brain, and skin inflammatory mediators - relevance to chronic fatigue syndrome
}

\author{
Magdalini Vasiadi ${ }^{1,2}$, Jennifer Newman ${ }^{3}$ and Theoharis C Theoharides ${ }^{1,2,4^{*}}$
}

\begin{abstract}
Background: Chronic Fatigue Syndrome (CFS) is a neuroimmunoendocrine disease affecting about $1 \%$ of the US population, mostly women. It is characterized by debilitating fatigue for six or more months in the absence of cancer or other systemic diseases. Many CFS patients also have fibromyalgia and skin hypersensitivity that worsen with stress. Corticotropin-releasing hormone $(\mathrm{CRH})$ and neurotensin (NT), secreted under stress, activate mast cells (MC) necessary for allergic reactions to release inflammatory mediators that could contribute to CFS symptoms.
\end{abstract}

Objective: To investigate the effect of isoflavones on the action of polyinosinic:polycytidylic acid (poly(l:C)), with or without swim stress, on mouse locomotor activity and inflammatory mediator expression, as well as on human MC activation.

Methods: Female C57BL/6 mice were randomly divided into four groups: (a) control/no-swim, (b) control/swim, (c) polyinosinic:polycytidylic acid (poly(l:C))/no swim, and (d) polyinosinic:polycytidylic acid (poly(l:C))/swim. Mice were provided with chow low or high in isoflavones for 2 weeks prior to ip injection with $20 \mathrm{mg} / \mathrm{kg}$ poly(l:C) followed or not by swim stress for 15 minutes. Locomotor activity was monitored overnight and animals were sacrificed the following day. Brain and skin gene expression, as well as serum levels, of inflammatory mediators were measured. Data were analyzed using the non-parametric Mann-Whitney U-test.

Results: Poly(l:C)-treated mice had decreased locomotor activity over 24 hours, and increased serum levels of TNF-a, IL-6, KC (IL-8/CXCL8 murine homolog), CCL2,3,4,5, CXCL10, as well as brain and skin gene expression of TNF, IL-6, KC (CXCl1, IL8 murine homolog), CCL2, CCL4, CCL5 and CXCL10. Histidine decarboxylase (HDC) and NT expression were also increased, but only in the skin, over the same period. High isoflavone diet reversed these effects.

Conclusion: Poly(l:C) treatment decreased mouse locomotor activity and increased serum levels and brain and skin gene expression of inflammatory mediators. These effects were inhibited by isoflavones that may prove useful in CFS.

Keywords: Brain, Fatigue, Inflammation, Isoflavones, Mast cells, Polyinosinic:polycytidylic acid, Skin, Stress, Swim

\section{Background}

Chronic Fatigue Syndrome (CFS) is a complex disease, which has also been called 'neurasthenia', 'post viral fatigue', and 'chronic mononucleosis' [1-3]. Its prevalence may be as high as $1 \%$ in the US population [4] with a female to male ratio of 4 to 1 [5]. CFS involves the muscular, nervous, hormonal and immune systems. Patients complain

\footnotetext{
* Correspondence: theoharis.theoharides@tufts.edu

'Department of Integrative Physiology and Pathobiology, Molecular Immunopharmacology and Drug Discovery Laboratory, Tufts University School of Medicine, 136 Harrison Avenue, Boston, MA 02111, USA ${ }^{2}$ Graduate Program in Pharmacology and Experimental Therapeutics, Sackler School of Graduate Biomedical Sciences, Tufts University, Boston, MA, USA Full list of author information is available at the end of the article
}

of overwhelming fatigue, sleep disturbances, malaise, muscle aches, gastrointestinal symptoms, dizziness on standing, and cognitive problems [6]. Clinical and subclinical viral infections have been suspected, but never confirmed $[7,8]$.

CFS is often comorbid with other disorders, including fibromyalgia, Pelvic Bladder Syndrome/Interstitial Cystitis (PBS/IC), irritable bowel syndrome (IBS), and migraines [9], all of which are characterized by central nervous system (CNS) dysfunction [10], and worsened by stress [11-15]. Many CFS patients demonstrate abnormal hypothalamic-pituitary-adrenal (HPA) axis activity [16,17]. Anxiety is common in CFS [18] and 
patients are particularly vulnerable to stress [14]. Many CFS symptoms could derive from the possible release of inflammatory mediators that could affect brain function $[19,20]$. As of today, there are no FDA approved drugs for the treatment of CFS [21]; psychological, physical, and pharmacological interventions used currently are not very effective [22].

An abnormal immune component may be involved in CFS [23-25], but the neuroimmune and neuroendocrine interactions involved are still unknown [26]. Mast cells (MC) and their mediators have been implicated in all diseases that are comorbid with CFS [9]. There is higher number of skin MC in patients with CFS [27,28], and such patients also show increased skin hypersensitivity [29]. Furthermore, CFS also occurs more often in patients with chronic urticaria, that also involves MC [30]. In fact, there is hyperresponsiveness in the bronchi of CFS patients, implying MC activation [31].

Activated MC release a number of chemokines and cytokines that could contribute to CFS symptoms $[32,33]$. MC are located perivascularly in close proximity to neurons [34], especially in the diencephalon $[35,36]$, where functional MC-neuron interactions have been documented [36,37] in response to corticotropinreleasing hormone $(\mathrm{CRH})$ [38]. In vivo activation of $\mathrm{MC}$ by CRH is augmented by neurotensin (NT) [39]. Moreover, NT is induced in the hypothalamus in response to bacterial lipopolysaccharide (LPS) and regulates the HPA axis [40].

Unfortunately, there are neither effective CFS treatments nor human MC inhibitors clinically available that may also be used in CFS. Flavonoids are natural compounds with strong antioxidant and anti-inflammatory activity [41]. Certain flavonoids also inhibit MC [42] and have neuroprotective effects $[41,43]$.

Here we report that treatment of mice with poly(I:C) results in reduced locomotor activity and increased serum levels, as well as brain and gene expression, of inflammatory mediators, all of which are reversed by treatment with the isoflavones daidzein and genistein.

\section{Methods}

\section{Chemicals and reagents}

Polyinosinic-polycytidylic acid-TLR3-based adjuvant, poly (I:C), HMW VacciGrade, (catalog\# vac-pic) was purchased from Invivogen (San Diego, CA, USA). Substance P (SP, catalog\# S6883), neurotensin (NT, catalog\# N6383) and corticotropin-releasing hormone (CRF, catalog\# C3042) were purchased from Sigma-Aldrich (St. Louis, MO, USA). Aliquots of the above were prepared according to the manufacturer's instructions. Teklad lab animal diets (catalog\# 2918X, and 2920X) were purchased from Harlan (Indianapolis, IN, USA).

\section{Animals}

C57BL/6 female mice, nine to twelve weeks old, (Jackson Laboratories, Bar Harbor, ME, USA) were kept in virus-free sections of a modern animal facility and were allowed ad libitum access to food and water. They were maintained on a 14:10 hour light-dark cycle (the standard light-dark cycle used by the Department of Animal Health). Female mice were chosen because published reports indicate a female to male ratio of 4:1 [5], while the US Centers for Disease Control and Prevention (CDC) specify a female to male ratio of 4:1 [5]. Mice were kept in cages of five mice/cage until the day of the experiments. Both low and high isoflavone diets (2018X and 2020X) were sterile with similar ingredients other than isoflavone content. We monitored weight changes for 21 days prior to the beginning of the experiments. Only poly(I:C)/no swim-treated mice showed a slight decrease in weight change. Poly(I:C)/swim-treated mice, as well as their corresponding control mice, slightly increased their weight over the three-week observation period. However, by the end of this period, there was no statistical difference in weight change. The protocol was approved by Tufts Medical Center IACUC under number B 2011-88.

\section{Treatment conditions}

Mice were provided with chow containing either nondetectable to low (ND-20 mg/kg, Teklad 2920X) or high (150 to $250 \mathrm{mg} / \mathrm{kg}$, Teklad 2918X) isoflavone (daidzein plus genistein) levels for two weeks. Conditions included four groups: (a) control (normal saline intraperitoneal (ip) injection)/no swim, (b) control/swim, (c) poly(I:C)/ no swim, and (d) poly(I:C)/swim ( $\mathrm{n}=5$ to $7 /$ group). Mice were injected ip with $20 \mathrm{mg} / \mathrm{kg}$ of poly(I:C) or normal saline the first day. Subsequently, they were subjected to swim for 15 minutes, individually in a transparent plastic cylindrical jar $(17 \mathrm{~cm} \times 25 \mathrm{~cm})$ containing $15 \mathrm{~cm}$-deep water at room temperature $\left(23 \pm 1^{\circ} \mathrm{C}\right)$. This approach reflects both exercise and the stress of water immersion. Mice were then placed individually into specific cages and locomotor activity was monitored overnight.

\section{Assessment of behavioral parameter-locomotor activity}

After the experimental procedures, animals were placed individually into standard plastic housing cages with food and water available ad libitum and overnight locomotor activity (for a total of 16 hours) was monitored with the Neuroscience Behavior Core's mouse SmartFrame ${ }^{\bullet}$ Cage Rack System (Kinder Scientific, Poway, CA, USA). This system consists of 20 PC-interfaced horizontal photobeam frames. The frame (containing 12 photocells; arranged on a $8 \mathrm{~L} \times 4 \mathrm{~W}$ grid) surrounds one home cage environment and continuously tracks the animal's movement. This fully automated system allows the user to quantify horizontal ambulation by counting breaks in infrared photocell 
beams using MotorMonitor software (Hamilton-Kinder Scientific, Poway, CA, USA). Data were collected and subsequently analyzed in time bins (every hour) or as a total over the course of collection to the 'Total Distance Travelled' (in $\mathrm{cm}$ ) parameter for each zone.

\section{Sample collection}

Mice were euthanized 24 hours post poly(I:C) ip injection using isoflurane overdose and thoracotomy. Blood was collected by cardiac puncture and was used to determine inflammatory mediator levels in the serum. Brain (diencephalon) and skin (back shaved with a electric shaver the day before) samples were collected and immersed into RNAlater (catalog\# AM7021) purchased from Invitrogen (Grand Island, NY, USA). Samples were stored at $-80^{\circ} \mathrm{C}$.

\section{Serum levels of inflammatory mediators}

TNF- $\alpha$, VEGF $\alpha$, IL-1 $\alpha$, IL-1 $\beta$, IL-4, IL-6, KC (IL-8/(CXC motif) ligand (CXC)L8 murine homolog, IL-9, IL-10, IL-12p70, IL-17, (CC motif) ligand (CCL)2, CCL3, CCL4, CCL5, CXCL10 and IFNY mouse serum levels were determined using the MILLIPLEX MAP Mouse Cytokine/Chemokine Magnetic Bead Assay (MCYTOMAG-70 K custom made panel for the specific analytes mentioned above). Measurements were performed blindly by Millipore (St. Charles, MI, USA). Millipore's minimum assay reporting range for TNF- $\alpha$ and IL- 6 levels was $32 \mathrm{pg} / \mathrm{ml}$, for CCL2 was $800 \mathrm{pg} / \mathrm{ml}$, while for CCL3 and CCL4 it was $160 \mathrm{pg} / \mathrm{ml}$. Therefore, we consider all values $<\times \mathrm{pg} / \mathrm{ml}$ as equal to $\mathrm{xpg} / \mathrm{ml}$.

\section{Quantitative PCR}

Total RNA from mouse tissues was extracted using RNeasy Plus Mini kit (catalog\# 74134) and RNeasy Fibrous Tissue Mini Kit (catalog\# 74704), purchased from QIAGEN (Valencia, CA, USA). Reverse transcription was performed with $300 \mathrm{ng}$ of total RNA using the iScript cDNA synthesis kit (catalog\# 170-8891) purchased from Bio-Rad (Hercules, CA, USA). Real-time quantitative polymerase chain reaction (qPCR) was carried out in a 7300 Sequence Detector, according to TaqMan Gene Expression Assay instructions from Life Technologies, Applied Biosystems (Grand Island, NY, USA) using Taqman primer/probe sets (Additional file 1: Table S1). Samples were analyzed for $\operatorname{Tnf}(T N F-\alpha), I l 4, I l 6$ (IL-6), KC (Cxcl1, $I L-8$ homolog in the mouse), Ccl2 (CCL2), Ccl4 (CCL4), Ccl5 (CCL5), Cxcl10 (CXCL10), histidine decarboxylase$H d c(H D C)$, and Nts (NT) gene expression using Gapdh as internal control.Thermal cycling proceeded at $50^{\circ} \mathrm{C}$ for 2 minutes, $95^{\circ} \mathrm{C}$ for 10 minutes, $95^{\circ} \mathrm{C}$ for 15 seconds, for 40 cycles, and $60^{\circ} \mathrm{C}$ for 1 minute. Negative controls included samples with water instead of template. Assays were performed in triplicate for each data point. Results were normalized against the endogenous gene GAPDH and were expressed relative to the mean of the control for each gene (relative fold change).

\section{Statistical analysis}

Data were analyzed using the non-parametric MannWhitney $U$-test. Results are presented as mean $\pm \mathrm{SE}$. Statistical significance is defined as $P<0.05$. We analyzed separately the different treatment subgroups within each dietary group, using Mann-Whitney $U$-test to compare poly(I:C)/no swim and poly(I:C)/swimtreated mice with the control/no swim and control/ swim-treated groups, accordingly. We then analyzed the same treatment subgroups between the two dietary groups, using Mann-Whitney $U$-test to compare, for example, poly(I:C)/swim-treated mice with low isoflavone diet to poly(I:C)/swim-treated mice that were provided with high isoflavone diet. Due to space limitations, we submitted figures composed of all the experimental conditions from the two different diets and all the statistical significant results were marked in these figures.

\section{Results}

Effect of poly $(\mathrm{l}: \mathrm{C})$ and isoflavones on locomotor activity

Poly(I:C)/swim and poly(I:C)/no swim-treated mice on low isoflavones had reduced maximum $(\max )$ locomotor activity (over the 10-hour night period), denoted by the dark bar $(P=0.008$ and $P=0.036)$ compared to the control/swim and control/no swim-treated mice, respectively (Figure 1A). High isoflavone chow reversed this decrease (Figure 1B), and the difference between the two diets was statistically significant $(P=0.032)$.

\section{Effect of poly $(\mathrm{l}: \mathrm{C})$ and isoflavones on serum inflammatory mediators}

Poly(I:C)-treated mice on low isoflavones had increased serum levels of TNF- $\alpha$ (Figure 2A), IL-6 (Figure 2B), KC (Figure 2C), and CCL4 (Figure 2D), as well as CCL2, CCL3, CCL5, and CXCL10 (Additional file 2: Table S2). High isoflavones reduced the poly(I:C)-increased serum levels of all the inflammatory markers. All IFN $\gamma$, IL-1 $\beta$, IL-4, IL-9, IL-10, IL-12p70, IL-17 and VEGF $\alpha$ serum levels were below the detection limit, while IL- $1 \alpha$ serum levels were similar between the different treatment groups. Swim stress augmented the poly(I:C) effect on TNF- $\alpha$, CCL4, and CCL 5 serum levels.

More specifically, TNF- $\alpha$ serum levels in poly(I:C)/ swim-treated mice on low isoflavones were increased $(55 \pm 14 \mathrm{pg} / \mathrm{ml})$ compared to control $/$ swim-treated mice $(32 \pm 0 \mathrm{pg} / \mathrm{ml}, \quad P=0.0011)$ and $p o l y(\mathrm{I}: \mathrm{C}) /$ no swimtreated mice $(37 \pm 10 \mathrm{pg} / \mathrm{ml}, P=0.0221)$. High isoflavones decreased these high TNF- $\alpha$ serum levels (32 \pm $0 \mathrm{pg} / \mathrm{ml}, P=0.0042$ ) (Figure 2A). IL-6 serum levels in poly(I:C)-swim and poly(I:C)/no swim-treated mice on 


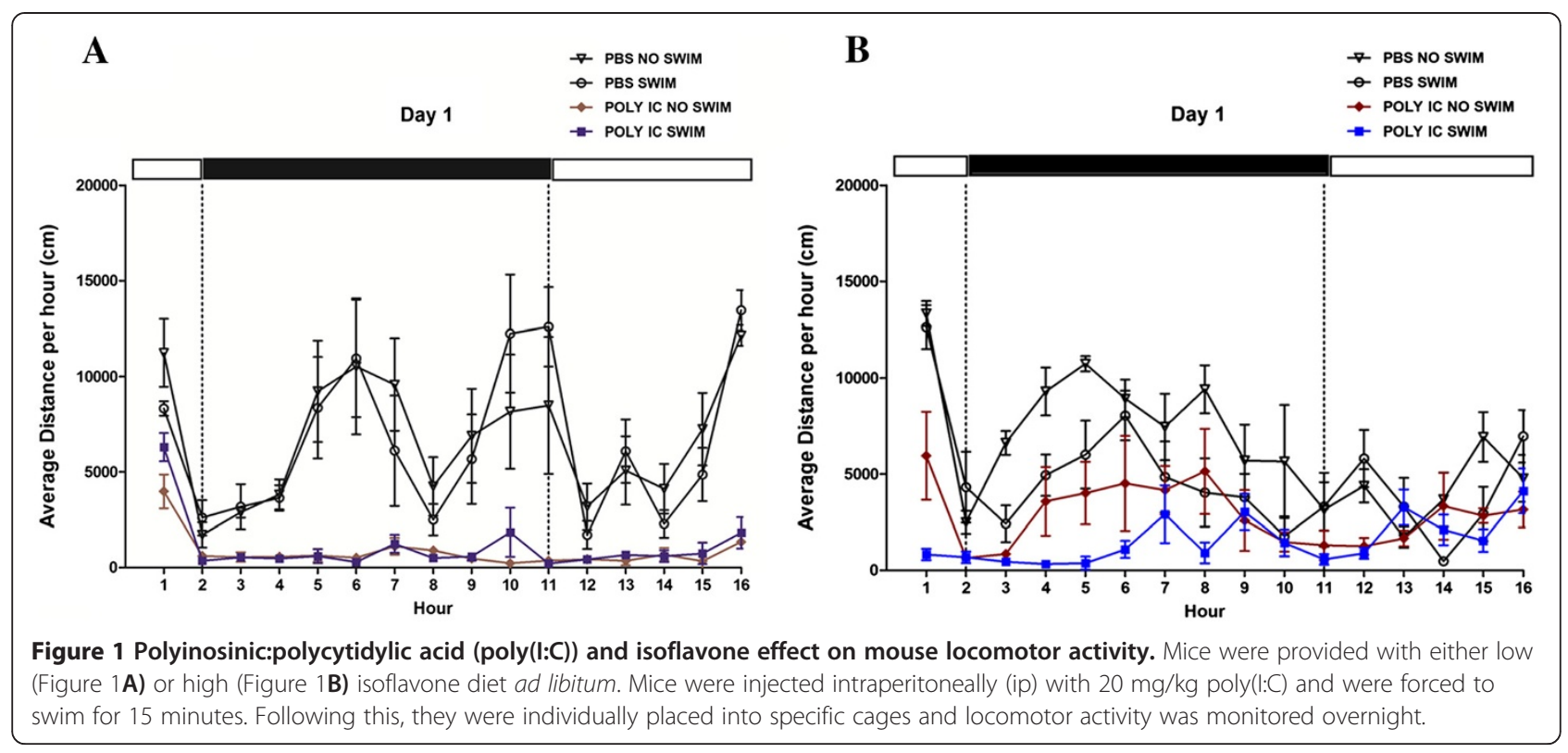

low isoflavones were also increased $(229 \pm 110 \mathrm{pg} / \mathrm{ml}$ and $141 \pm 11 \mathrm{pg} / \mathrm{ml}$ ) compared to the corresponding control/swim and control/no swim mice on low isoflavones $(32 \pm 0 \mathrm{pg} / \mathrm{ml}, P=0.0011$ and $32 \pm 0 \mathrm{pg} / \mathrm{ml}, P=0.0114)$ (Figure 2B). High isoflavones reduced IL-6 serum levels of poly(I:C)/swim-treated mice $(35 \pm 5 \mathrm{pg} / \mathrm{ml}, P=0.0054)$ and poly(I:C)/no swim-treated $(32 \pm 0 \mathrm{pg} / \mathrm{ml}, P=0.0298)$ compared to the corresponding groups on low isoflavones (Figure 2B).

Similarly, KC serum levels in poly(I:C)-treated mice on low isoflavones were increased $(735 \pm 579 \mathrm{pg} / \mathrm{ml}$ and $626 \pm 523 \mathrm{pg} / \mathrm{ml}$ ) compared to the corresponding controls $(173 \pm 43 \mathrm{pg} / \mathrm{ml}, P=0.0379$ and $132 \pm 52 \mathrm{pg} / \mathrm{ml}$, $P=0.0006$, respectively) (Figure $2 \mathrm{C}$ ). Although $\mathrm{KC}$ serum levels in poly(I:C)/swim-treated mice on high isoflavones were also increased $(451 \pm 107 \mathrm{pg} / \mathrm{ml})$ compared to control poly(I:C)/swim-treated mice $(100 \pm 45 \mathrm{pg} / \mathrm{ml}$, $P=0.0079)$, high isoflavone diet decreased $\mathrm{KC}$ serum levels in poly(I:C)/no swim-treated mice $(128 \pm 43 \mathrm{pg} / \mathrm{ml}$, $P=0.0025)$ compared to those on low isoflavones (Figure 2C).

Moreover, CCL4 serum levels were increased in poly (I:C)-treated mice on low isoflavones $(1,256 \pm 556 \mathrm{pg} / \mathrm{ml}$ and $395 \pm 245 \mathrm{pg} / \mathrm{ml}$ ) compared to the corresponding controls $(160 \pm 0 \mathrm{pg} / \mathrm{ml}, P=0.0011$ and $160 \pm 0 \mathrm{pg} / \mathrm{ml}$, $P=0.0037$, respectively) (Figure 2D). Swim further increased CCL4 serum levels $(1,256 \pm 556 \mathrm{pg} / \mathrm{ml}$, $P=0.0023)$. Although CCL4 serum levels in poly(I:C)treated mice on high isoflavones were also increased $(217 \pm 55 \mathrm{pg} / \mathrm{ml}$ and $265 \pm 111 \mathrm{pg} / \mathrm{ml})$ compared to their controls $(160 \pm 0 \mathrm{pg} / \mathrm{ml}, P=0.0075$ and $160 \pm 0 \mathrm{pg} / \mathrm{ml}$, $P=0.0254$, respectively)., high isoflavones decreased
CCL4 serum levels in poly(I:C)/swim-treated mice (217 \pm $55 \mathrm{pg} / \mathrm{ml}, P=0.0025$ ) (Figure 2D).

Poly(I:C) treatment also increased CCL2, CCL3, CCL5 and CXCL10 serum levels and high isoflavones reduced those increases (Additional file 3).

\section{Effect of poly(l:C) and isoflavones on brain gene expression of inflammatory mediators}

TNF- $\alpha$ (Figure 3A), IL-6 (Figure 3B), KC (Figure 3C), CCL4 (Figure 3D), as well as CCL2, CCL5 and CXCL10 brain gene expression were increased in the poly $(\mathrm{I}: \mathrm{C})$ treated mice. High isoflavones reduced the increased TNF, IL6, KC, CCL4 and CCL2 brain gene expression. There was no difference in $H D C$ and $N T$ gene expression between the different treatment groups (Additional file 4: Table S3).

More specifically TNF- $\alpha$ gene expression was increased in the brain of poly(I:C)-treated mice on low isoflavones (relative fold change of $22 \pm 7$ and $12 \pm 9$ ) compared to their controls $(1.1 \pm 0.9, P=0.0006$ and $1 \pm 0.7, P=0.0012$, respectively) (Figure $3 \mathrm{~A}$ ). Although poly(I:C)-treated mice on high isoflavones had increased TNF- $\alpha$ brain gene expression $(6 \pm 1$ and $9 \pm 8)$ compared to their corresponding controls $(1.2 \pm 0.5, P=0.0079$ and $1 \pm 0.3$, $P=0.0079$, respectively), high isoflavones decreased TNF- $\alpha$ gene expression in the brain of poly(I:C)/swimtreated mice $(6 \pm 1, P=0.0025)$ compared to those on low isoflavones (Figure 3A). There was no effect of poly(I:C) treatment on $I L-6$ brain gene expression (Figure $3 \mathrm{~B}$ ), but high isoflavones still decreased $I L-6$ gene expression in the brain of poly(I:C)/swim-treated mice $(0.5 \pm 0.1$, 

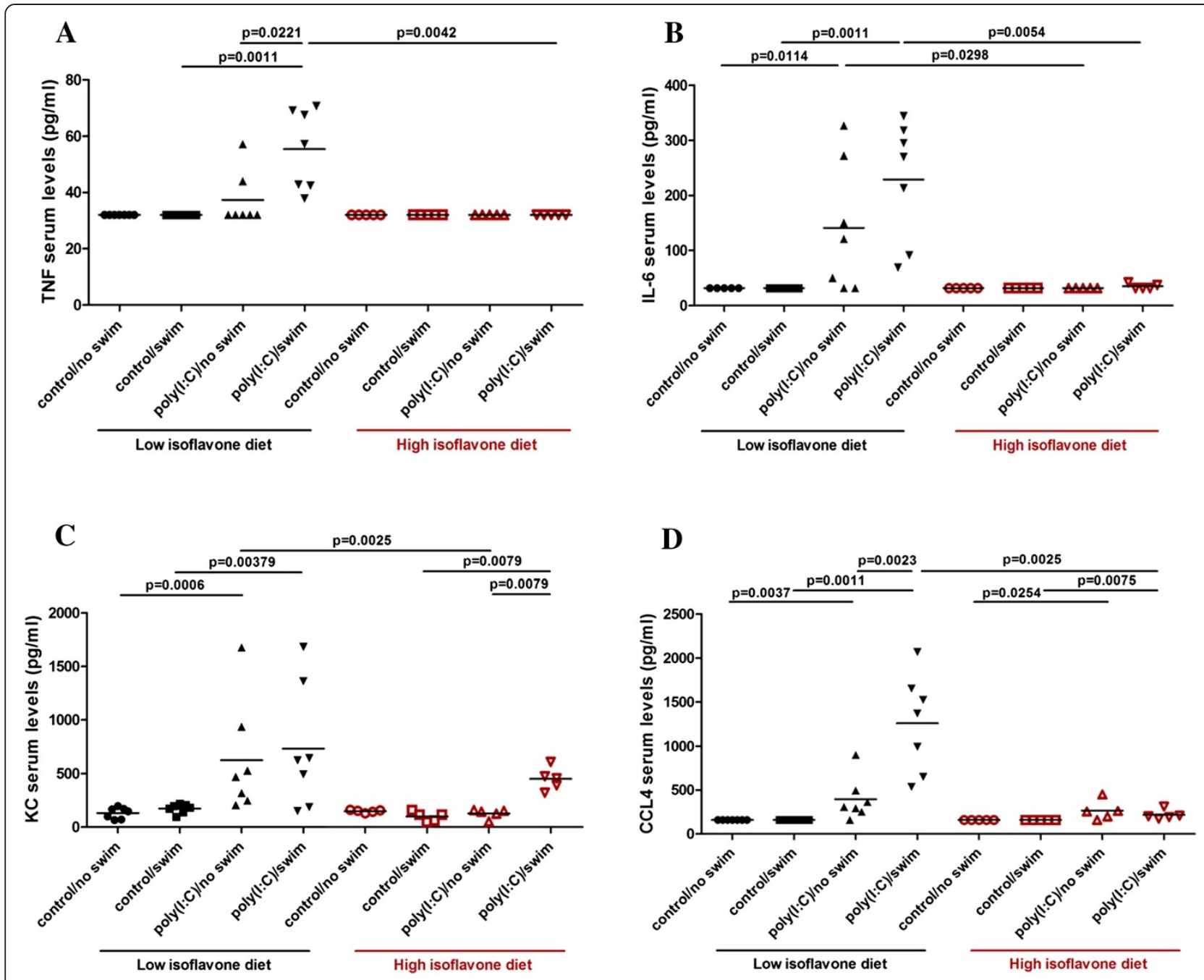

Figure 2 Polyinosinic:polycytidylic acid (poly(l:C)) and isoflavone effect on serum levels of inflammatory mediators. Mice were provided with either low or high isoflavone diet ad libitum. Mice were injected intraperitoneally (ip) with $20 \mathrm{mg} / \mathrm{kg}$ poly(l:C) and were forced to swim for $15 \mathrm{minutes}$. Following this, they were individually placed into specific cages and locomotor activity was monitored overnight. The next day, serum samples were collected and analyzed for TNF-a (Figure 2A), IL-6 (Figure 2B), KC (Figure 2C), and CCL4 (Figure 2D) using the Milliplex microbead assay.

$P=0.0228)$ compared to those on low isoflavones $(2.1 \pm$ 2.4) (Figure 3B).

$K C$ gene expression in the brain of poly(I:C)-treated mice on low isoflavones was increased $(18 \pm 13$ and $40 \pm 52)$ compared to their controls $(0.9 \pm 0.3, P=0.0006$ and $1 \pm 0.3$, $P=0.0183$, respectively) (Figure $3 \mathrm{C}$ ). Although poly(I:C)/ swim-treated mice on high isoflavones still had increased $K C$ gene expression in their brain $(2 \pm 0.9)$ compared to control/ swim-treated mice $(0.6 \pm 0.1, P=0.0159)$, high isoflavones reduced this increase in $K C$ gene expression $(2 \pm 0.9$, $P=0.0177)$ compared to poly(I:C)/swim-treated mice on low isoflavones (Figure $3 \mathrm{C}$ ).

Likewise, CCL4 gene expression in the brain of poly(I:C)treated mice on low isoflavones was also increased $(6.5 \pm 4$ and $2.9 \pm 1.6)$ compared to their controls $(1 \pm 0.3, P=0.0006$ and $1 \pm 0.4, P=0.0350$, respectively) (Figure $3 \mathrm{D}$ ). Although,
poly(I:C)/swim-treated mice on high isoflavones still had increased CCL4 gene expression $(1.8 \pm 0.4)$ compared to control/swim-treated mice $(1 \pm 0.4, P=0.0317)$, high isoflavones reduced this increase in CCL4 gene expression (1.8 \pm 0.4 , $P=0.0101)$ compared to poly(I:C)/swim-treated mice on low isoflavones (Figure 3D). Poly(I:C) treatment also increased CCL2, CCL5 and CXCL1O gene expression in the brains of the mice. High isoflavones reduced this noted CCL2 brain gene expression increase (Additional file 3).

\section{Effect of poly(l:C) and isoflavones on skin gene expression of inflammatory mediators}

TNF- $\alpha$ (Figure 4A), IL-6 (Figure 4B), KC (Figure 4C), CCL4 (Figure 4D), as well as CCL2, CCL5 and CXCL1O (Additional file 5: Table S4) skin gene expression were increased in the poly(I:C)-treated mice. Moreover, $H D C$ 


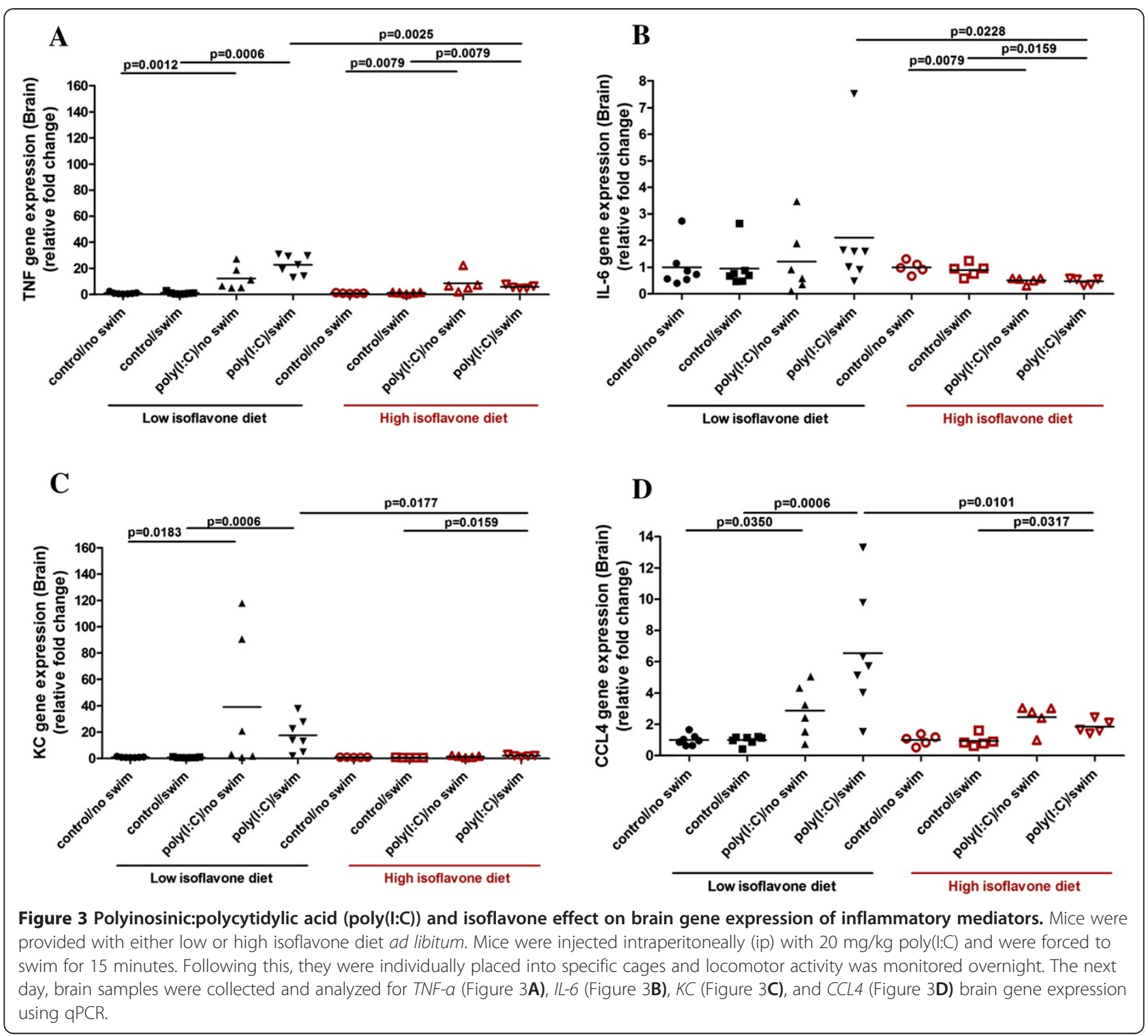

and $N T$ gene expression were also increased in the skin (Figure 5A and B). High isoflavone diet reduced the increased TNF- $\alpha, I L-6$ and $K C$ skin gene expression.

More specifically, TNF- $\alpha$ gene expression in the skin of poly(I:C)/swim-treated mice on low isoflavones, was increased $(5 \pm 0.9)$ compared to their controls $(1.1 \pm 0.4$, $P=0.0006$ ) (Figure $4 \mathrm{~A}$ ) and high isoflavones decreased this increase in $T N F-\alpha$ gene expression $(2.3 \pm 1.3$, $P=0.0101$ ) (Figure 4A). Likewise, $I L-6$ gene expression in the skin of poly(I:C)-treated mice on low isoflavones was increased $(14 \pm 4$ and $22 \pm 16)$ compared to their controls $(0.9 \pm 0.8, P=0.0006$ and $1 \pm 0.4, P=0.0012$, respectively) (Figure 4B). Although poly(I:C)-treated mice on high isoflavones still had increased $I L-6$ gene expression (5.5 \pm 3 and $3.4 \pm 1.7$ ) compared to their controls $(1.4 \pm 0.7, P=0.0079$ and $0.7 \pm 0.4, P=0.0159$, respectively), high isoflavones reduced this increase in the $I L-6$ gene expression $(5.5 \pm 3 P=0.0101)$ (Figure 4B).

Similarly, $K C$ gene expression in the skin of poly(I:C)treated mice on low isoflavones was also increased (53 \pm 55 and $69 \pm 83)$ compared to their controls $(0.3 \pm 0.2$, $P=0.0021$ and $1 \pm 1.5, P=0.0012$, respectively) (Figure $4 \mathrm{C}$ ). High isoflavones reduced this increase in the $K C$ gene expression of poly(I:C)-treated mice $(2.8 \pm 3.5, P=0.0057$ and $3.4 \pm 1.9, P=0.0043$ ) (Figure $4 \mathrm{C}$ ).

CCL4 gene expression was increased in the skin of poly (I:C)-treated mice on low isoflavones $(24 \pm 15$ and $21 \pm 19)$ compared to their controls $(0.4 \pm 0.3, P=0.0021$ and $1 \pm$ $1.7, P=0.0023$, respectively) (Figure $4 \mathrm{D}$ ). CCL4 gene expression was also increased in the skin of poly(I:C)-treated mice on high isoflavones $(20 \pm 24$ and $27 \pm 20)$ compared to their controls $(0.8 \pm 0.7, P=0.0079$ and $1 \pm 1.3, P=0.0079$, 


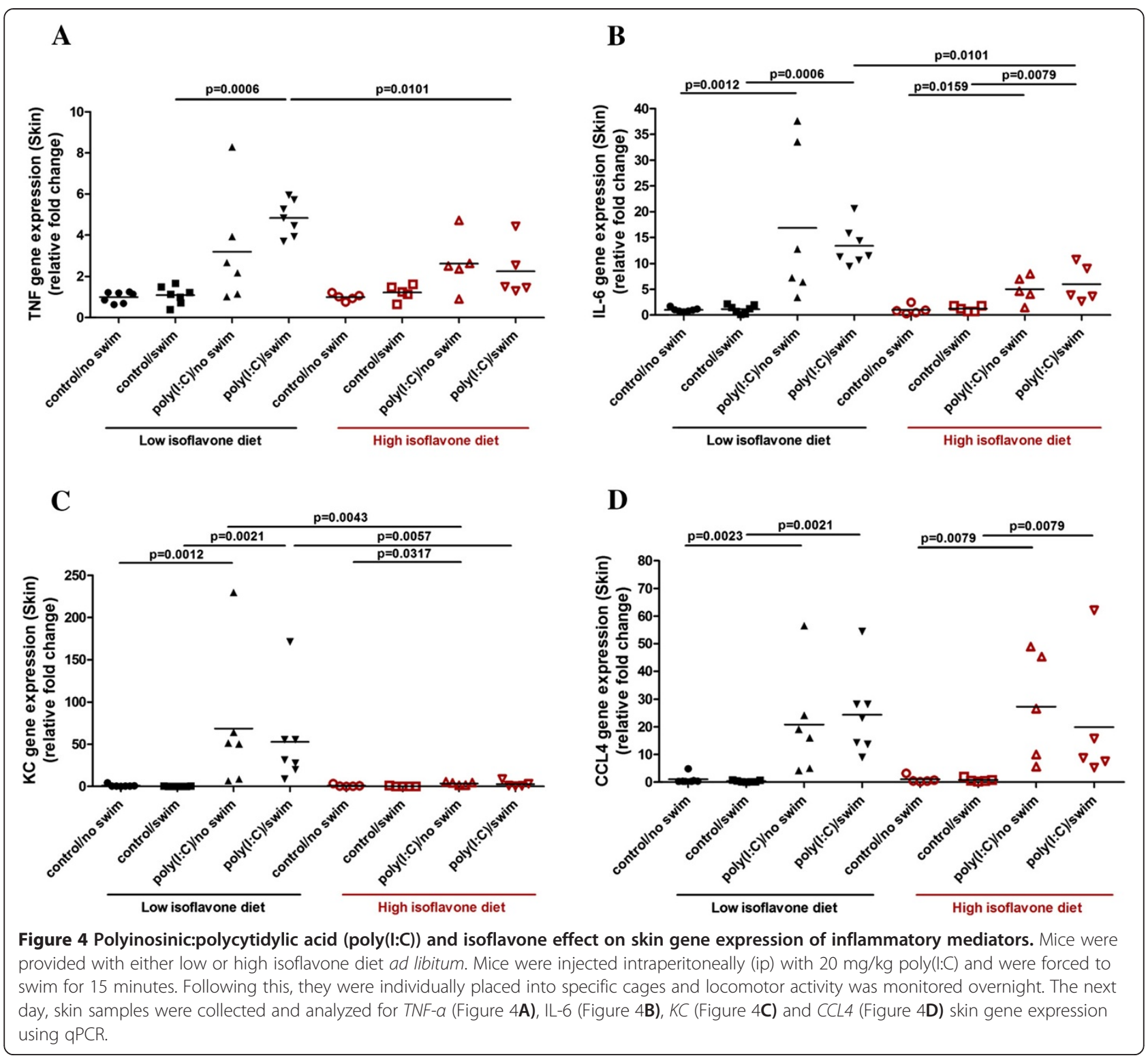

respectively) and high isoflavones did have an effect on reducing this increase.

In the same way, $H D C$ gene expression was increased in the skin of poly(I:C)-treated mice on low isoflavones $(4 \pm 2$ and $4 \pm 2)$ compared to their controls $(0.6 \pm 0.4, P=0.0003$ and $1 \pm 0.8, P=0.0123$, respectively) (Figure $5 \mathrm{~A}$ ). $H D C$ gene expression was also increased in the skin of poly(I:C)treated mice on high isoflavones $(3 \pm 1.1$ and $3 \pm 1)$ compared to their controls $(0.9 \pm 0.3, P=0.0079$ and $1 \pm 0.2$, $P=0.0317$, respectively).

Similar to $H D C$ gene expression, $N T$ gene expression was increased in the skin of poly(I:C)-treated mice on low isoflavones $(8 \pm 4$ and $9 \pm 10)$ compared to their controls (0.6 $\pm 0.4, P=0.0025$ and $1 \pm 0.7, P=0.0012$, respectively) (Figure 5B). NT gene expression was also increased in the skin of poly(I:C)-treated mice on high isoflavones $(8 \pm 4$, and $6 \pm 6)$ compared to their controls $(1.9 \pm 0.8, P=0.0317$ and $1 \pm 0.2, P=0.0079$, respectively).

Finally, poly(I:C) treatment also increased CCL2, CCL5 and CXCL10 gene expression in the skin of the mice. High isoflavones did not have any statistical effect on CCL4, CCL2, CCL5, CXCL10, HDC and NT skin gene expression (Additional file 5: Table S4).

\section{Discussion}

Here we show that poly(I:C) significantly reduced locomotor activity over the first 24 hours, in comparison to control mice. Forced swim did not have any effect on its own, but augmented the effect of poly(I:C) on increasing TNF- $\alpha$, CCL3 and CCL5 serum levels. We also used BALBc mice in an effort to investigate the possibility of 

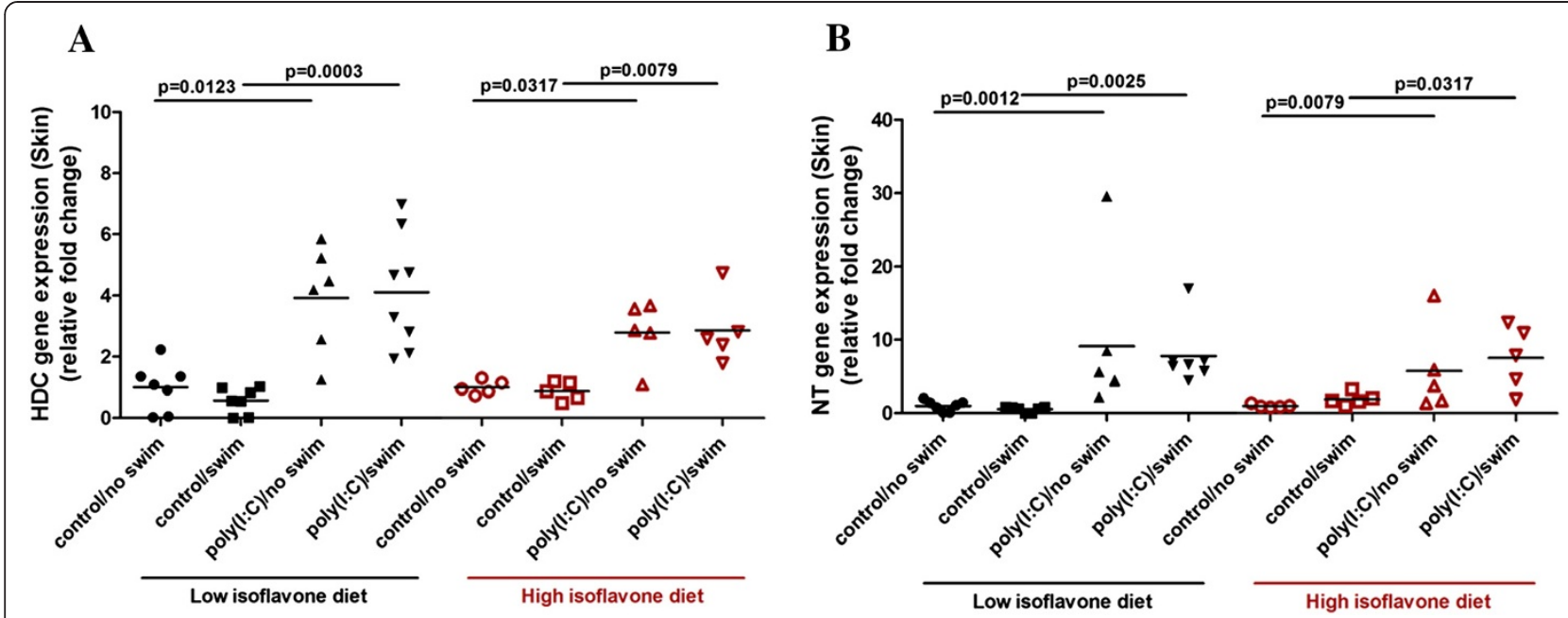

Figure 5 Polyinosinic:polycytidylic acid (poly $(\mathrm{l}: \mathrm{C})$ ) and isoflavone effect on skin gene expression of inflammatory mediators. Mice were provided with either low or high isoflavone diet ad libitum. Mice were injected intraperitoneally (ip) with $20 \mathrm{mg} / \mathrm{kg}$ poly(l:C) and were forced to swim for 15 minutes. Following this, they were individually placed into specific cages and locomotor activity was monitored overnight. The next day, skin samples were collected and analyzed for HDC (Figure 5A) and NT (Figure 5B) skin gene expression using qPCR.

strain differences, but there was no difference from our findings with C57BL/6 mice (results not shown).

Use of poly(I:C) increased serum levels of molecules that have been associated with inflammation and fatigue including TNF- $\alpha, \mathrm{IL}-6, \mathrm{KC}$, CCL2, CCL3, CCL4, CCL5, and CXCL10. Moreover, poly(I:C) also increased brain and skin gene expression of TNF- $\alpha, I L-6, K C, C C L 2$, CCL4, CCL5, CXCL10, while HDC and NT gene expression were only increased in the skin, suggesting that NT and histamine may explain the skin findings in CFS patients. Forced swim stress had no additional effect to that of poly(I:C), except for augmenting TNF- $\alpha$ serum levels. TNF- $\alpha$ and IL- 6 serum levels were actually increased in CFS $[20,44]$. Such pro-inflammatory mediators can increase blood-brain barrier (BBB) permeability [45] and permit entry of circulating leukocytes leading to brain inflammation. TNF- $\alpha$ was shown to be released along with histamine from rat brain $\mathrm{MC}$ [46], and was involved in brain inflammation [47]. MC can also interact with $T$ cells [48-50] and superactivate them through TNF- $\alpha[51]$.

Unlike our present results, one group reported that daily forced swim stress for two to three weeks, with or without an immunological trigger administered on day one (lipopolysaccharide or Brucella abortus antigen), induced 'chronic fatigue', but only in Albino laca mice [52-55] and Wistar rats [56]. In these papers, behavioral parameters, such as immobility time, time to start grooming after swim stress, roda rod test, and elevated plus maze test were increased indicating post stress fatigue and anxiety. Also, biochemical measurements indicative of brain oxidative stress were increased. In another paper, BALBc mice were injected with Brucella abortus and developed decreased running activity that lasted one week [57]. Forced swim of Charles Foster albino rats for twenty-one days also increased immobility time, anxiety as assessed by elevated plus maze test, and brain oxidative stress [58]. These findings maybe due to the differences in the strains and triggers used.

Chemokines interact with their receptors and attract immune cells to inflammation sites [59-61]. CXCR1, CXCR2, CXCR3, CXCR4, CX3CR1, CCR1, CCR3, CCR4 and CCR5 are expressed by human MC of different origins [62]. Stimulated MC release CCL2, CCL3, CCL4 [63]. Murine fetal skin-derived cultured MC (FSMCs) release CCL3, CCL4, CCL5, IL- 6 and TNF- $\alpha$ upon TLR3poly(I:C) activation $[64,65]$. Peritoneal MC from C57BL/ 6 mice activated by poly(I:C)-TLR3 have increased CCL5 and CXCL10 expression $[66,67]$.

Here we also show that poly(I:C) with or without NT or CRH did not have any effect on TNF- $\alpha$, CXCL8 and VEGF $\alpha$ release from human cultured LAD2 MC (results not shown), but increased only TNF- $\alpha$ gene expression when used together with $\mathrm{CRH}, \mathrm{NT}$, or SP. Poly(I:C) alone did not have any effect on human $\mathrm{MC}$, but increased TNF- $\alpha$ gene expression at 24 hours when used together with CRH or NT.

Toll-like receptors' (TLRs) $[68,69]$ activation is important in the development of innate immunity to invading pathogens, leading to release of different cytokines [64,70,71]. Antigen-mediated MC reactivity is amplified through prolonged TLR-ligand treatment [72].

Human umbilical cord blood-derived MC express TLR-3, activation of which produced IFN $\alpha$ and IFN $\beta$ in response to double-stranded RNA [73]. A recent publication reported that $\mathrm{MC}$ respond to intracellular, but 
not extracellular, poly(I:C) by inducing mainly IFN $\alpha$ and TNF- $\alpha$; moreover, infection of MC with live Sendai virus induces an anti-viral response similar to that of intracellular poly(I:C) [74].

We also used CRHR-1 knockout (KO) mice in order to investigate the possible involvement of CRHR in any stress effect. However, forced swim stress alone did not have an effect and there was no difference using these mice (results not shown). Nevertheless, rats exposed to water immersion stress had a four-fold increase in plasma histamine levels that was absent in $\mathrm{W} / \mathrm{W}^{\mathrm{V}} \mathrm{MC}$ deficient rats [75]. Acute stress also increased serum histamine and IL-6 levels, both of which were also absent in $\mathrm{MC}$ deficient $\mathrm{W} / \mathrm{W}^{\mathrm{v}}$ mice [76].

Here we also show that the isoflavones genistein and daidzein reversed the effect of poly(I:C) on mice. Genistein has been reported to attenuate muscle fatigue [77], protect against endothelial barrier dysfunction [78] and suppress LPS-induced inflammatory response in macrophages [79]. Isoflavones also suppress $\mathrm{MC}$ expression of the high affinity IgE receptor (FceRI) [80]. However, isoflavones have estrogenic activity and may not be desirable in certain clinical settings. The flavonoids epigallocatechin, naringin, and curcumin ameliorated 'chronic fatigue' [53-56]. Other papers reported similar effects for the Astragalus flavonoids [81] and for the olive extract [82].

Flavonoids exert potent anti-inflammatory effects via various pathways [83-87]. A review of human randomized controlled trial studies summarized some significant benefits to cognitive function after isoflavone supplementation [88]: improvements in executive function, working memory and processing speed [88]. Specifically, two studies reported significant effects of $60 \mathrm{mg} /$ day treatment with isoflavones in processing speed and psychomotor speed $[89,90]$.

Quercetin increases exercise tolerance in mice [91]. Oral administration of quercetin leads to accumulation in brain tissue and attenuates the increased oxidative stress in the hippocampus and striatum of rats exposed to chronic forced swimming $[92,93]$. Quercetin has potent anti-oxidant and anti-inflammatory activity $[41,42]$, and inhibits MC degranulation [94,95], as well as TNF$\alpha$, IL-6, and IL-8 secretion [95,96]. Moreover, it reverses acute stress-induced behavioral changes and reduces brain glutathione levels in mice [97].

Recent studies with antigen-stimulated MC show that epigallocatechin gallate (EGCG) inhibits MC degranulation, leukotriene $\mathrm{C}_{4}$ secretion, as well as the production of TNF$\alpha$, IL-6 and IL-8 [94,96]. The quercetin-related flavone luteolin inhibits MC activation [98] and MC-dependent stimulation of activated $\mathrm{T}$ cells [51]. Luteolin also inhibits IL-6 release from microglia cells [99] and from astrocytes [100]. Recent reviews have addressed the possible use of flavonoids for the treatment of CNS diseases [101,102].
Increasing evidence implicates CNS inflammation [103], as well as MC-microglia interactions, in neuropsychiatric diseases [104,105]. MC are important for allergic reactions, but also in immunity [106,107], and inflammatory diseases $[15,108]$. TLRs have also been implicated in CNS dysfunction through MC and glial activation [104].

\section{Conclusion}

Here we report that treatment of mice with poly(I:C) resulted in reduced locomotor activity and increased inflammatory markers in serum, brain and skin, all of which were reversed by treatment with isoflavones. Our findings also demonstrate significant variability among mouse 'models' as was recently reported [109]. There is need for the establishment of a more reliable animal model for CFS. Nevertheless, certain flavonoids appear promising for use in pilot clinical trials with CFS patients.

\section{Additional files}

Additional file 1: Table S1. Additional detailed results for each analyte. Additional file 2: Table S2. Serum levels of inflammatory mediators. Additional file 3: Additional results.

Additional file 4: Table S3. Brain gene expression of inflammatory mediators.

Additional file 5: Table S4. Skin gene expression of inflammatory mediators.

\section{Abbreviations}

AD: atopic dermatitis; BBB: blood-brain barrier; CCL: (CC motif) ligand; CDC: US Centers for Disease Control and Prevention; CFS: Chronic Fatigue Syndrome; CNS: central nervous system; $\mathrm{CRH}$ : corticotropin-releasing hormone; CRHR-1: CRH receptor-1; CXC: (CXC motif) ligand;

EGCG: epigallocatechin gallate; FSMC: murine fetal skin-derived cultured MC; HDC: histidine decarboxylase; HPA: hypothalamic-pituitary-adrenal; PBS/ IC: Pelvic Bladder Syndrome/Interstitial Cystitis; IBS: irritable bowel syndrome; IFN: interferon; IL: interleukin; ip: intraperitoneal; KC: keratinocyte-derived chemokine (murine CXCL8/IL-8 homolog); KO: knockout;

LPS: lipopolysaccharide; MC: mast cells; NT: neurotensin; PCR: polymerase chain reaction; Poly(l:C): polyinosinic:polycytidylic acid; SP: substance P; TLRs: Toll-like receptors; TNF: tumor necrosis factor; VEGF: vascular endothelial growth factor.

\section{Competing interests}

The authors declare that they have no competing interests.

\section{Authors' contributions}

MV planned and carried out all the studies, analyzed the results and participated in the writing of the manuscript. JN supervised the behavioral studies and helped with the interpretation of the results. TCT conceptualized the overall project, provided the funding, discussed the results and their significance, and participated in the writing of the manuscript. All authors read and approved the final manuscript.

\section{Acknowledgments}

We thank Dr. AS Kirshenbaum, National Institutes of Health, NIH for his kindly providing the LAD2 cells. We thank Dr. J Bloomberg (Friedman School of Nutrition Science and Policy) for measurements of brain oxidative stress. We thank Sweden Orphan Biovitrum AB (Stockholm, Sweden) for the kind supply of the recombinant human stem cell factor (rhSCF). This work was supported by National Institutes of Health grant (NS71361) to TCT. We thank 
Dr. Benjamin Natelson (Beth Israel Medical Center, NY, NY) for ongoing useful suggestions and Smaro Panagiotidou for her word processing skills.

\section{Disclosures}

TCT has been awarded US Patent Number 8,268,365, entitled 'Anti-inflammatory compositions for treating brain inflammation'.

\section{Author details}

'Department of Integrative Physiology and Pathobiology, Molecular Immunopharmacology and Drug Discovery Laboratory, Tufts University School of Medicine, 136 Harrison Avenue, Boston, MA 02111, USA. ${ }^{2}$ Graduate Program in Pharmacology and Experimental Therapeutics, Sackler School of Graduate Biomedical Sciences, Tufts University, Boston, MA, USA. ${ }^{3}$ Department of Neuroscience, Tufts University, School of Medicine, Boston, MA, USA. ${ }^{4}$ Department of Internal Medicine, Tufts University School of Medicine and Tufts Medical Center, Boston, MA, USA.

Received: 7 April 2014 Accepted: 17 September 2014

Published online: 31 October 2014

\section{References}

1. Jason LA, Corradi K, Torres-Harding S, Taylor RR, King C: Chronic fatigue syndrome: the need for subtypes. Neuropsychol Rev 2005, 15:29-58.

2. Jahan F, Nanji K, Qidwai W, Qasim R: Fibromyalgia syndrome: an overview of pathophysiology, diagnosis and management. Oman Med J 2012, 27:192-195.

3. Anderson VR, Jason LA, Hlavaty LE, Porter N, Cudia J: A review and metasynthesis of qualitative studies on myalgic encephalomyelitis/chronic fatigue syndrome. Patient Educ Couns 2012, 86:147-155.

4. Van't LM, Zielhuis GA, van der Meer JW, Verbeek AL, Bleijenberg G: Fatigue and chronic fatigue syndrome-like complaints in the general population. Eur J Public Health 2010, 20:251-257.

5. Griffith JP, Zarrouf FA: A systematic review of chronic fatigue syndrome: don't assume it's depression. Prim Care Companion J Clin Psychiatry 2008, 10:120-128.

6. Holgate ST, Komaroff AL, Mangan D, Wessely S: Chronic fatigue syndrome: understanding a complex illness. Nat Rev Neurosci 2011, 12:539-544.

7. Katz BZ, Shiraishi Y, Mears CJ, Binns HJ, Taylor R: Chronic fatigue syndrome after infectious mononucleosis in adolescents. Pediatrics 2009, 124:189-193.

8. Fremont M, Metzger K, Rady H, Hulstaert J, De MK: Detection of herpesviruses and parvovirus B19 in gastric and intestinal mucosa of chronic fatigue syndrome patients. In Vivo 2009, 23:209-213.

9. Theoharides TC: Atopic conditions in search of pathogenesis and therapy. Clin Ther 2013, 35:544-547.

10. Martinez-Martinez LA, Mora T, Vargas A, Fuentes-Iniestra M, Martinez-Lavin M: Sympathetic nervous system dysfunction in fibromyalgia, chronic fatigue syndrome, irritable bowel syndrome, and interstitial cystitis: a review of case-control studies. J Clin Rheumatol 2014, 20:146-150.

11. Aaron LA, Buchwald D: Fibromyalgia and other unexplained clinical conditions. Curr Rheumatol 2001, 3:116-122.

12. Abbi $B$, Natelson $B H$ : Is chronic fatigue syndrome the same illness as fibromyalgia: evaluating the 'single syndrome' hypothesis. QJM 2013, 106:3-9.

13. Aaron LA, Buchwald D: Chronic diffuse musculoskeletal pain, fibromyalgia and co-morbid unexplained clinical conditions. Best Prac Res Clin Rheumatol 2003, 17:563-574.

14. Smith MS, Martin-Herz SP, Womack WM, Marsigan JL: Comparative study of anxiety, depression, somatization, functional disability, and illness attribution in adolescents with chronic fatigue or migraine. Pediatrics 2003, 111:e376-e381.

15. Theoharides TC, Cochrane DE: Critical role of mast cells in inflammatory diseases and the effect of acute stress. J Neuroimmunol 2004, 146:1-12.

16. Gur A, Oktayoglu P: Central nervous system abnormalities in fibromyalgia and chronic fatigue syndrome: new concepts in treatment. Curr Pharm Des 2008, 14:1274-1294.

17. Cleare AJ, Miell J, Heap E, Sookdeo S, Young L, Malhi GS, O'Keane V: Hypothalamo-pituitary-adrenal axis dysfunction in chronic fatigue syndrome, and the effects of low-dose hydrocortisone therapy. J Clin Endocrinol Metab 2001, 86:3545-3554.
18. Crawley E, Hunt L, Stallard P: Anxiety in children with CFS/ME. Eur Child Adolesc Psychiatry 2009, 18:683-689.

19. Theoharides TC, Weinkauf C, Conti P: Brain cytokines and neuropsychiatric disorders. J Clin Psychopharmacol 2004, 24:577-581.

20. Maes M, Twisk FN, Ringel K: Inflammatory and cell-mediated immune biomarkers in myalgic encephalomyelitis/chronic fatigue syndrome and depression: inflammatory markers are higher in myalgic encephalomyelitis/ chronic fatigue syndrome than in depression. Psychother Psychosom 2012, 81:286-295.

21. Pae CU, Marks DM, Patkar AA, Masand PS, Luyten P, Serretti A: Pharmacological treatment of chronic fatigue syndrome: focusing on the role of antidepressants. Expert Opin Pharmacother 2009, 10:1561-1570.

22. Huang L, Frampton G, Rao A, Zhang KS, Chen W, Lai JM, Yin XY, Walker K, Culbreath B, Leyva-Illades D, Quinn M, McMillin M, Bradley M, Liang $\sqcup$, DeMorrow S: Monoamine oxidase A expression is suppressed in human cholangiocarcinoma via coordinated epigenetic and IL-6-driven events. Lab Invest 2012, 92:1451-1460.

23. Bansal AS, Bradley AS, Bishop KN, Kiani-Alikhan S, Ford B: Chronic fatigue syndrome, the immune system and viral infection. Brain Behav Immun 2012, 26:24-31.

24. Dietert RR, Dietert JM: Possible role for early-life immune insult including developmental immunotoxicity in chronic fatigue syndrome (CFS) or myalgic encephalomyelitis (ME). Toxicology 2008, 247:61-72.

25. Bower JE: Fatigue, brain, behavior, and immunity: summary of the 2012 Named Series on fatigue. Brain Behav Immun 2012, 26:1220-1223.

26. Klimas NG, Broderick G, Fletcher MA: Biomarkers for chronic fatigue. Brain Behav Immun 2012, 26:1202-1210.

27. Blanco I, Beritze N, Arguelles M, Carcaba V, Fernandez F, Janciauskiene S, Oikonomopoulou K, De Serres FJ, Fernandez-Bustillo E, Hollenberg MD: Abnormal overexpression of mastocytes in skin biopsies of fibromyalgia patients. Clin Rheumatol 2010, 29:1403-1412.

28. Enestrom S, Bengtsson A, Frodin T: Dermal lgG deposits and increase of mast cells in patients with fibromyalgia-relevant findings or epiphenomena? Scand J Rheumatol 1997, 26:308-313.

29. Steinberg P, Pheley A, Peterson PK: Influence of immediate hypersensitivity skin reactions on delayed reactions in patients with chronic fatigue syndrome. J Allergy Clin Immunol 1996, 98:1126-1128.

30. Yener M, Erturan I, Ceyhan AM, Inal EE, Kozanoglu OO: The evaluation of prevalence of fibromyalgia in patients with chronic urticaria. Med Sci Monit 2013, 19:757-761.

31. Nijs J, De BP, De MK, Demanet C, Vincken W, Schuermans D, McGregor N: Associations between bronchial hyperresponsiveness and immune cell parameters in patients with chronic fatigue syndrome. Chest 2003, 123:998-1007

32. Theoharides TC, Papaliodis D, Tagen M, Konstantinidou A, Kempuraj D, Clemons A: Chronic fatigue syndrome, mast cells, and tricyclic antidepressants. J Clin Psychopharmacol 2005, 25:515-520.

33. Theoharides TC, Donelan JM, Papadopoulou N, Cao J, Kempuraj D, Conti P. Mast cells as targets of corticotropin-releasing factor and related peptides. Trends Pharmacol Sci 2004, 25:563-568.

34. Paus R, Theoharides TC, Arck PC: Neuroimmunoendocrine circuitry of the 'brain-skin connection'. Trends Immunol 2006, 27:32-39.

35. Theoharides TC, Konstantinidou A: Corticotropin-releasing hormone and the blood-brain-barrier. Front Biosci 2007, 12:1615-1628.

36. Rozniecki JJ, Dimitriadou V, Lambracht-Hall M, Pang X, Theoharides TC: Morphological and functional demonstration of rat dura mast cellneuron interactions in vitro and in vivo. Brain Res 1999, 849:1-15.

37. Dimitriadou V, Rouleau A, Trung Tuong MD, Newlands GJF, Miller HRP, Luffau G, Schwartz J-C, Garbarg M: Functional relationships between sensory nerve fibers and mast cells of dura mater in normal and inflammatory conditions. Neuroscience 1997, 77:829-839.

38. Theoharides TC, Spanos CP, Pang X, Alferes L, Ligris K, Letourneau R, Rozniecki JJ, Webster E, Chrousos G: Stress-induced intracranial mast cell degranulation. A corticotropin releasing hormone-mediated effect. Endocrinology 1995, 136:5745-5750.

39. Donelan J, Boucher W, Papadopoulou N, Lytinas M, Papaliodis D, Theoharides TC: Corticotropin-releasing hormone induces skin vascular permeability through a neurotensin-dependent process. Proc Natl Acad Sci U S A 2006, 103:7759-7764.

40. Nicot A, Rowe WB, De Kloet ER, Betancur C, Jessop DS, Lightman SL, Quirion R, Rostene W, Berod A: Endogenous neurotensin regulates 
hypothalamic-pituitary-adrenal axis activity and peptidergic neurons in the rat hypothalamic paraventricular nucleus. J Neuroendocrinol 1997, 9:263-269.

41. Middleton EJ, Kandaswami C, Theoharides TC: The effects of plant flavonoids on mammalian cells: implications for inflammation, heart disease and cancer. Pharmacol Rev 2000, 52:673-751.

42. Kempuraj D, Madhappan B, Christodoulou S, Boucher W, Cao J, Papadopoulou N, Cetrulo CL, Theoharides TC: Flavonols inhibit proinflammatory mediator release, intracellular calcium ion levels and protein kinase $C$ theta phosphorylation in human mast cells. Br J Pharmacol 2005, 145:934-944.

43. Miranda CL, Maier CS, Stevens JF: Flavonoids. Chichester: eLS. John Wiley \& Sons, Ltd; 2012. doi:10. 1002/9780470015902. a0003068. pub2.

44. Uceyler N, Hauser W, Sommer C: Systematic review with meta-analysis: cytokines in fibromyalgia syndrome. BMC Musculoskelet Disord 2011, 12:245.

45. Abbott NJ: Inflammatory mediators and modulation of blood-brain barrier permeability. Cell Mol Neurobiol 2000, 20:131-147.

46. Cocchiara R, Bongiovanni A, Albeggiani G, Azzolina A, Geraci D: Evidence that brain mast cells can modulate neuroinflammatory responses by tumor necrosis factor-a production. Neuroreport 1998, 9:95-98.

47. Probert L, Akassoglou K, Kassiotis G, Pasparakis M, Alexopoulou L, Kollias G: TNF-a transgenic and knockout models of CNS inflammation and degeneration. J Neuroimmunol 1997, 72:137-141.

48. Bachelet I, Levi-Schaffer F: Mast cells as effector cells: a co-stimulating question. Trends Immunol 2007, 28:360-365.

49. Salamon P, Shoham NG, Gavrieli R, Wolach B, Mekori YA: Human mast cells release interleukin- 8 and induce neutrophil chemotaxis on contact with activated T cells. Allergy 2005, 60:1316-1319.

50. Nakae S, Suto H, likura M, Kakurai M, Sedgwick JD, Tsai M, Galli SJ: Mast cells enhance $T$ cell activation: importance of mast cell costimulatory molecules and secreted TNF. J Immunol 2006, 176:2238-2248.

51. Kempuraj D, Tagen M, lliopoulou BP, Clemons A, Vasiadi M, Boucher W, House M, Wolferg A, Theoharides TC: Luteolin inhibits myelin basic protein-induced human mast cell activation and mast cell dependent stimulation of Jurkat T cells. Br J Pharmacol 2008, 155:1076-1084

52. Sachdeva AK, Kuhad A, Tiwari V, Arora V, Chopra K: Protective effect of epigallocatechin gallate in murine water-immersion stress model of chronic fatigue syndrome. Basic Clin Pharmacol Toxicol 2010, 2010:2010.

53. Sachdeva AK, Kuhad A, Tiwari V, Chopra K: Epigallocatechin gallate ameliorates chronic fatigue syndrome in mice: behavioral and biochemical evidence. Behav Brain Res 2009, 205:414-420.

54. Vij G, Gupta A, Chopra K: Modulation of antigen-induced chronic fatigue in mouse model of water immersion stress by naringin, a polyphenolic antioxidant. Fundam Clin Pharmacol 2009, 23:331-337.

55. Gupta A, Vij G, Sharma S, Tirkey N, Rishi P, Chopra K: Curcumin, a polyphenolic antioxidant, attenuates chronic fatigue syndrome in murine water immersion stress model. Immunobiology 2009, 214:33-39.

56. Sachdeva AK, Kuhad A, Chopra K: Epigallocatechin gallate ameliorates behavioral and biochemical deficits in rat model of load-induced chronic fatigue syndrome. Brain Res Bull 2011, 86:165-172

57. Ottenweller JE, Natelson BH, Gause WC, Carroll KK, Beldowicz D, Zhou XD, LaManca JJ: Mouse running activity is lowered by Brucella abortus treatment: a potential model to study chronic fatigue. Physiol Behav 1998, 63:795-801.

58. Surapaneni DK, Adapa SR, Preeti K, Teja GR, Veeraragavan M, Krishnamurthy S: Shilajit attenuates behavioral symptoms of chronic fatigue syndrome by modulating the hypothalamic-pituitary-adrenal axis and mitochondrial bioenergetics in rats. J Ethnopharmacol 2012, 143:91-99.

59. Moser B, Wolf M, Walz A, Loetscher P: Chemokines: multiple levels of leukocyte migration control. Trends Immunol 2004, 25:75-84.

60. Charo IF, Ransohoff RM: The many roles of chemokines and chemokine receptors in inflammation. N Engl J Med 2006, 354:610-621.

61. Koelink PJ, Overbeek SA, Braber S, De KP, Folkerts G, Smit MJ, Kraneveld AD: Targeting chemokine receptors in chronic inflammatory diseases: an extensive review. Pharmacol Ther 2012, 133:1-18.

62. Juremalm M, Nilsson G: Chemokine receptor expression by mast cells. Chem Immunol Allergy 2005, 87:130-144.

63. Oliveira SH, Lukacs NW: Stem cell factor and lgE-stimulated murine mast cells produce chemokines (CCL2, CCL17, CCL22) and express chemokine receptors. Inflamm Res 2001, 50:168-174.

64. Sandig H, Bulfone-Paus S: TLR signaling in mast cells: common and unique features. Front Immunol 2012, 3:185.
65. Matsushima H, Yamada N, Matsue H, Shimada S: TLR3-, TLR7-, and TLR9mediated production of proinflammatory cytokines and chemokines from murine connective tissue type skin-derived mast cells but not from bone marrow-derived mast cells. J Immunol 2004, 173:531-541.

66. Orinska Z, Bulanova E, Budagian V, Metz M, Maurer M, Bulfone-Paus S: TLR3induced activation of mast cells modulates CD8+ T-cell recruitment. Blood 2005, 106:978-987.

67. Ott VL, Cambier JC, Kappler J, Marrack P, Swanson BJ: Mast cell-dependent migration of effector CD8+ T cells through production of leukotriene B4. Nat Immunol 2003, 4:974-981.

68. Akira S, Takeda K, Kaisho T: Toll-like receptors: critical proteins linking innate and acquired immunity. Nat Immunol 2001, 2:675-680.

69. Aderem A, Ulevitch RJ: Toll-like receptors in the induction of the innate immune response. Nature 2000, 406:782-787.

70. Okayama Y: Mast cell-derived cytokine expression induced via Fc receptors and Toll-like receptors. Chem Immunol Allergy 2005, 87:101-110.

71. Vercammen E, Staal J, Beyaert R: Sensing of viral infection and activation of innate immunity by toll-like receptor 3. Clin Microbiol Rev 2008, 21:13-25.

72. Saluja R, Delin I, Nilsson GP, Adner M: FcepsilonR1-mediated mast cell reactivity is amplified through prolonged Toll-like receptor-ligand treatment. PLoS One 2012, 7:e43547.

73. Kulka M, Alexopoulou L, Flavell RA, Metcalfe DD: Activation of mast cells by double-stranded RNA: evidence for activation through Toll-like receptor 3. J Allergy Clin Immunol 2004, 114:174-182.

74. Lappalainen J, Rintahaka J, Kovanen PT, Matikainen S, Eklund KK: Intracellular RNA recognition pathway activates strong anti-viral response in human mast cells. Clin Exp Immunol 2013, 172:121-128.

75. Huang Z, Mochizuki T, Watanabe H, Kagoshima M, Maeyama K: Biphasic evaluation of plasma histamine induced by water immersion stress, and their sources in rats. Eur J Pharmacol 1998, 360:139-146.

76. Huang M, Berry J, Kandere K, Lytinas M, Karalis K, Theoharides TC: Mast cell deficient $W / W^{v}$ mice lack stress-induced increase in serum IL-6 levels, as well as in peripheral $\mathrm{CRH}$ and vascular permeability, a model of rheumatoid arthritis. Int J Immunopathol Pharmacol 2002, 15:249-254.

77. Ding W, Liu Y: Genistein attenuates genioglossus muscle fatigue under chronic intermittent hypoxia by down-regulation of oxidative stress level and up-regulation of antioxidant enzyme activity through ERK1/2 signaling pathway. Oral Dis 2011, 17:677-684.

78. Jia Z, Zhen W, Velayutham Anandh BP, Liu D: Phytoestrogen genistein protects against endothelial barrier dysfunction in vascular endothelial cells through PKA-mediated suppression of RhoA signaling. Endocrinology 2013, 154:727-737.

79. Ji G, Zhang Y, Yang Q, Cheng S, Hao J, Zhao X, Jiang Z: Genistein suppresses LPS-induced inflammatory response through inhibiting NFkappaB following AMP kinase activation in RAW 264.7 macrophages. PLoS One 2012, 7:e53101.

80. Yamashita S, Tsukamoto S, Kumazoe M, Kim YH, Yamada K, Tachibana H: Isoflavones suppress the expression of the FcepsilonRI high-affinity immunoglobulin $\mathrm{E}$ receptor independent of the estrogen receptor. J Agric Food Chem 2012, 60:8379-8385.

81. Kuo YH, Tsai WJ, Loke SH, Wu TS, Chiou WF: Astragalus membranaceus flavonoids (AMF) ameliorate chronic fatigue syndrome induced by food intake restriction plus forced swimming. J Ethnopharmacol 2009, 122:28-34.

82. Gupta A, Vij G, Chopra K: Possible role of oxidative stress and immunological activation in mouse model of chronic fatigue syndrome and its attenuation by olive extract. J Neuroimmunol 2010, 226(1-2):3-7.

83. Shaulian E, Karin M: AP-1 as a regulator of cell life and death. Nat Cell Biol 2002, 4:E131-E136.

84. Hess J, Angel P, Schorpp-Kistner M: AP-1 subunits: quarrel and harmony among siblings. J Cell Sci 2004, 117:5965-5973.

85. Fraga CG, Oteiza PI: Dietary flavonoids: role of (-)-epicatechin and related procyanidins in cell signaling. Free Radic Biol Med 2011, 51:813-823.

86. Surh YJ, Kundu JK, Na HK: Nrf2 as a master redox switch in turning on the cellular signaling involved in the induction of cytoprotective genes by some chemopreventive phytochemicals. Planta Med 2008, 74:1526-1539.

87. Yang Y, Oh JM, Heo P, Shin JY, Kong B, Shin J, Lee JC, Oh JS, Park KW, Lee $\mathrm{CH}$, Shin YK, Kweon DH: Polyphenols differentially inhibit degranulation of distinct subsets of vesicles in mast cells by specific interaction with granule-type-dependent SNARE complexes. Biochem J 2013, 450:537-546. 
88. Macready AL, Kennedy OB, Ellis JA, Williams CM, Spencer JP, Butler LT: Flavonoids and cognitive function: a review of human randomized controlled trial studies and recommendations for future studies. Genes Nutr 2009, 4:227-242.

89. Casini ML, Marelli G, Papaleo E, Ferrari A, D'Ambrosio F, Unfer V: Psychological assessment of the effects of treatment with phytoestrogens on postmenopausal women: a randomized, doubleblind, crossover, placebo-controlled study. Fertil Steril 2006, 85:972-978.

90. Duffy R, Wiseman H, File SE: Improved cognitive function in postmenopausal women after 12 weeks of consumption of a soya extract containing isoflavones. Pharmacol Biochem Behav 2003, 75:721-729.

91. Davis JM, Murphy EA, Carmichael MD, Davis B: Quercetin increases brain and muscle mitochondrial biogenesis and exercise tolerance. Am J Physiol Regul Integr Comp Physiol 2009, 296:R1071-R1077.

92. Youdim KA, Qaiser MZ, Begley DJ, Rice-Evans CA, Abbott NJ: Flavonoid permeability across an in situ model of the blood-brain barrier. Free Radic Biol Med 2004, 36:592-604.

93. Ishisaka A, Ichikawa S, Sakakibara H, Piskula MK, Nakamura T, Kato Y, Ito M, Miyamoto K, Tsuji A, Kawai Y, Terao J: Accumulation of orally administered quercetin in brain tissue and its antioxidative effects in rats. Free Radic Biol Med 2011, 51:1329-1336.

94. Inoue T, Suzuki Y, Ra C: Epigallocatechin-3-gallate inhibits mast cell degranulation, leukotriene C4 secretion, and calcium influx via mitochondrial calcium dysfunction. Free Radic Biol Med 2010, 49:632-640.

95. Park HH, Lee S, Son HY, Park SB, Kim MS, Choi EJ, Singh TS, Ha JH, Lee MG, Kim JE, Hyun MC, Kwon TK, Kim YH, Kim SH: Flavonoids inhibit histamine release and expression of proinflammatory cytokines in mast cells. Arch Pharm Res 2008, 31:1303-1311.

96. Shin HY, Kim SH, Jeong HJ, Kim SY, Shin TY, Um JY, Hong SH, Kim HM: Epigallocatechin-3-gallate inhibits secretion of TNF-alpha, IL-6 and IL-8 through the attenuation of ERK and NF-kappaB in HMC-1 cells. Int Arch Allergy Immunol 2007, 142:335-344.

97. Kumar A, Goyal R: Quercetin protects against acute immobilization stressinduced behaviors and biochemical alterations in mice. J Med Food 2008, 11:469-473

98. Asadi S, Zhang B, Weng Z, Angelidou A, Kempuraj D, Alysandratos KD Theoharides TC: Luteolin and thiosalicylate inhibit $\mathrm{HgCl}(2)$ and thimerosal-induced VEGF release from human mast cells. Int J Immunopathol Pharmacol 2010, 23:1015-1020.

99. Jang S, Kelley KW, Johnson RW: Luteolin reduces IL-6 production in microglia by inhibiting JNK phosphorylation and activation of AP-1. Proc Natl Acad Sci U S A 2008, 105:7534-7539.

100. Sharma V, Mishra M, Ghosh S, Tewari R, Basu A, Seth P, Sen E: Modulation of interleukin-1beta mediated inflammatory response in human astrocytes by flavonoids: implications in neuroprotection. Brain Res Bull 2007, 73:55-63.

101. Jager AK, Saaby L: Flavonoids and the CNS. Molecules 2011, 16:1471-1485.

102. Jones QR, Warford J, Rupasinghe HP, Robertson GS: Target-based selection of flavonoids for neurodegenerative disorders. Trends Pharmacol Sci 2012, 33:602-610.

103. Theoharides TC, Zhang B, Conti P: Decreased mitochondrial function and increased brain inflammation in bipolar disorder and other neuropsychiatric diseases. J Clin Psychopharmacol 2011, 31:685-687.

104. Aguirre A, Maturana CJ, Harcha PA, Saez JC: Possible involvement of TLRs and hemichannels in stress-induced CNS dysfunction via mastocytes, and glia activation. Mediators Inflamm 2013, 2013:893521.

105. Skaper SD, Giusti P, Facci L: Microglia and mast cells: two tracks on the road to neuroinflammation. FASEB J 2012, 26:3103-3117.

106. Galli SJ, Borregaard N, Wynn TA: Phenotypic and functional plasticity of cells of innate immunity: macrophages, mast cells and neutrophils. Nat Immunol 2011, 12:1035-1044.

107. St John AL, Abraham SN: Innate immunity and its regulation by mast cells. J Immunol 2013, 190:4458-4463.

108. Theoharides TC: Mast cell: a neuroimmunoendocrine master player. Int $J$ Tissue React 1996, 18:1-21.
109. Seok J, Warren HS, Cuenca AG, Mindrinos MN, Baker HV, Xu W, Richards DR, Donald-Smith GP, Gao H, Hennessy L, Finnerty CC, Lopez CM, Honari S, Moore EE, Minei JP, Cuschieri J, Bankey PE, Johnson JL, Sperry J, Nathens AB, Billiar TR, West MA, Jeschke MG, Klein MB, Gamelli RL, Gibran NS, Brownstein BH, Miller-Graziano C, Calvano SE, Mason PH, et al: Genomic responses in mouse models poorly mimic human inflammatory diseases. PNAS 2013, 110:3507-3512.

doi:10.1186/s12974-014-0168-5

Cite this article as: Vasiadi et al:: Isoflavones inhibit poly(l:C)-induced serum, brain, and skin inflammatory mediators - relevance to chronic fatigue syndrome. Journal of Neuroinflammation 2014 11:168.

\section{Submit your next manuscript to BioMed Central and take full advantage of:}

- Convenient online submission

- Thorough peer review

- No space constraints or color figure charges

- Immediate publication on acceptance

- Inclusion in PubMed, CAS, Scopus and Google Scholar

- Research which is freely available for redistribution

Submit your manuscript at www.biomedcentral.com/submit
C Biomed Central 